\title{
The jouissance of the Torturer in Zero Dark Thirty and the Enjoyment of the Unacceptable
}

\author{
Juliet Rogers, University of Melbourne ${ }^{1}$
}

Torturers enjoy violence. This might be the very definition of a torturer. The enjoyment of the torturer in the scene of violence is emblematised in the ways in which the victim is produced in the scene. This might be as an object, as figuren as in the case of victims of the Nazi Holocaust; it might be as vehicles for the furthering of an ideal; or specifically, it might be as animated matter as in the scene of state sanctioned torture. In each of these scenes all or some of the modes of production of the victim may be at work, but in each of these scenes it is the use of the victim which defines the enjoyment of the perpetrator; use, as emblematized in the particular arrangement of that person as necessary to the perpetrator's enjoyment.

My interest is in the particular production of the victim in the practice of the torturer and in some instances for perpetrators of violence more broadly, and the impact of this arrangement on the victim, to understand this it is perhaps helpful to confront the dynamics engaged in particular scenes of violence, and examine the textures of these dynamics as they relate to the perpetrator's enjoyment of the acts. That is, to understand the impacts on the victims it is helpful—although often uncomfortable—to consider the

\footnotetext{
${ }^{1}$ Dr Juliet Rogers teaches in the department of Criminology, University of Melbourne. Much of this work is inspired by conversations with Dori Laub, my warmest thanks for his generosity and insight. This work departs from our conversations via its hefty Lacanian emphasis, however, and the mistakes are, of course, my own.
} 
particularities of how some perpetrators experience themselves in the scene of violence, because it is precisely this scene which the victims themselves often want to understand. ${ }^{2}$ These particularities, understood through Lacanian psychoanalysis, can be understood as contingent on the texture of the perpetrator's identification with either the regime, the law, their superiors or with the victim. Violence, in this sense, can be seen as a particular and often aggressively invested, practice of the performance of identity, and as a desire to produce a particular and invested reality for the regime, for oneself and about oneself.

In the terms of Jacques Lacan, the perpetrator always performs an address to the Other, ${ }^{3}$ and this Other exists, not as the person in front of them, in fact precisely not, but as the location from which the recognition of their deed comes. There are perpetrators who certainly exercise violence in an effort to achieve this recognition in an ordinaryalthough certainly violent sense from the perspective of the victim - but there are also those for whom the recognition is not required. These are the omnipotent, narcissistic perpetrators whose actions emanate from their own authority. These are the subjects who perceive themselves not as subject, but as the definitive authority from where both positive law_ —as an emblem of justice — and from where oedipal law —as an emblem of right-emanates. From these two poles we can understand a continuum of identification and dis-identification for the perpetrator with the law, God, the father, with their superiors, or even with the victim - what Lacan would call the (big O) Other, as the one who prohibits and proscribes the enjoyments of the subject. What is of interest in these modes of identification, particularly in the field of trauma, is to understand how the locations of identification (or dis-identification) can produce a particular enjoyment in some perpetrators and specifically those who torture, as what Lacan has coined a jouissance - as a relation of excitement or enjoyment evoked through a proximity to prohibition and to the sanction of identity as right. An enjoyment that appears at the point when positive law sanctions and oedipal law prohibits; an enjoyment which the victim experiences and in which torturers may revel, repeatedly.

\footnotetext{
${ }^{2}$ In both my work as a therapist with survivors of trauma and in my research I have heard, almost without exception, the question from survivors: 'why me?'

${ }^{3}$ We can understand this extrapolated by Lacan specifically in relation to criminality, and while my concern here is not with the legality or conviction of the perpetrator, Lacan's discussions on this are pertinent because the acts of perpetrators cannot be separated from the judgment of the law. See Lacan's Ecrits (Lacan 2006c [1966]).
} 


\section{The omnipotent torturer}

The omnipotent perpetrator is the psychotic for whom the violence is a creation of the reality they envision without the necessity of sanctioning that reality in the eyes of others. Adolf Hitler might be the most obvious of the examples from European history, but we can speculate about other examples in immediate history, such as: Charles Graner, the 'ringleader' in the Abu Ghraib scenes of torture; perhaps Anders Breivik in Norway; even Eugene de Kock the head of the South African Apartheid regime's secret assassination and torture organization, Vlakplaas. These are generally charismatic figures precisely because they exist without doubt; they like to take the law into their own hands, sometimes literally, because they believe, at the time, that it is their law.

This form of omnipotence - and its infantile trajectory - is well illustrated in the script of Ariel Dorfman's play Death and the Maiden (1994), in the 'confession' of Dr Miranda, a torturer who represented the interests of a repressive state. In Dorfman's play Paulina - the woman who was raped and tortured by Dr Miranda some 20 years prior-has captured Dr Miranda, and wants to kill, maim, or torture him in retribution for his treatment of her, and also to facilitate the extraction of a confession. Dr Miranda does confess, in some version, and we see the dynamics at play in his indication of his rationales and his enjoyment of the acts of torture. These document both his floating of oedipal law and his obedience to the state, that latter of which is emblematised in a righteous belief. As he says:

The real real truth, it was for humanitarian reasons. We're at war, I thought, they want to kill me and my family, they want to install a totalitarian dictatorship, but even so, they still have the right to some form of medical attention. It was slowly, almost without realizing how, that I became involved in more delicate operations, they let me sit in on sessions where my role was to determine if the prisoners could take that much torture, that much electric current. At first I told myself that it was a way of saving people's lives, and I did, because many times I told them-without it being true, simply to help the person who was being tortured-I ordered them to stop or the prisoner would die. But afterwards I began to- - bit by bit, the virtue I was feeling turned into excitementthe mask of virtue fell off it and it, the excitement, it hid, it hid, it hid from me what I was doing, the swamp of what-By the time Paulina Salas was brought in it was already too late. Too late.

... too late. A kind of-brutalization took over my life, I began to really truly like what I was doing. It became a game. My curiosity was partly morbid, partly scientific. How much can this woman take? More than the other one? How's her sex? Does her sex dry up when you put the current through her? Can she have an orgasm under those circumstances? She is entirely in your power, you can carry out all your fantasies, you can do what you want with her.

Everything they have forbidden you since ever, whatever your mother urgently whispered you were never to do. You began to dream with her, with all those women. (Dorfman 1994: 41-42) 
Excitement, curiosity, benevolence, ${ }^{4}$ flouting a childish prohibition—-these are Miranda’s rationales. They announce neither regret nor remorse. He is not apologetic, nor does he speak of any recognition of Paulina's humanity, pain or suffering. His curiosity suggests (perhaps) a recognition that he knew there was another person there. She is not an object, she has different feelings or at least responses to his own but even these feelings become part of the enjoyment. She is not object in the usual sense that we ascribe to perpetrator's relations with their victims; she is a person whose responses he enjoyed manipulating; she is his to subject. These are responses that prompt his attention and his desire. His 'confession' is more a reverie on what he could do to the victims, and how much he enjoyed doing it, rather than an indication that he did not, or should not have enjoyed it.

To understand this performance of enjoyment in the scene of such violence we must understand the dynamics of prohibition and their interaction between positive law's prohibitions. Or, in the case of acts such as Miranda's, and indeed of most torturers, we must understand the relation between the performance of acts of what we call internationally “crimes against humanity” —and are readily understood as breeches of oedipal law — when they are sanctioned by the law of the state. ${ }^{5}$ That is, it is helpful to understand how the rendering of the unacceptable in oedipal law-described by Miranda as 'whatever your mother urgently whispered you were never to do' - is experienced by the perpetrator when it becomes acceptable in positive law. What I will discuss below is how the rendering of that which is prohibited through oedipal law into 'what you could or even must do' under the instructions and sanctions of the state, produces a particular form of enjoyment; one which we can understand as a jouissance.

To understand jouissance we need to trace the subject's trajectory in relation to oedipal and positive law. What psychoanalysis has traced is that the subject is born omnipotent, but comes to know itself as constantly in a state of fragmentation. For Lacan, the infant that sees itself in the mirror wants to become that imago and constantly attempts to relive the Ideal- I it 'takes itself to be.' It is not that the infant only wants to replicate

\footnotetext{
${ }^{4}$ The benevolence is in part a specific device in the plot of the play, since allowing the victims to live also meant that the 'commission' set up in the fictional country that Paulina lives will only investigate incidents where deaths occur. This suggests that Miranda will never face the investigative or judicial powers of the state. Retributive justice is not possible for Paulina.

${ }^{5}$ For a discussion of the almost comprehensive sanction of law in the perpetration of 'crimes against humanity,' see Balint (2011), and for a specific discussion of the sanction of torture by law and lawyers in contemporary USA, see Sands (2008).
} 
what it has seen, however, but how it imagines itself seen by the Other. As Lacan says: 'It suffices to understand the mirror stage as an identification, in the full sense analysis gives to the term: namely, the transformation that takes place in the subject when he assumes [assume] as image' (Lacan 2006c: 76). This is an identification with its image in the gaze of the one who sees. The one who the infant imagines sees all. This figure is firstly the Mother, but then the Father, who 'may be regarded as the original representative of the Law's authority,' and this location of Law's authority can then be replaced by God, by the Fuhrer, or by law itself. This location is the site from which we understand the Lacanian Other is located, not as a specific person or rule, but as a site from which a person regarded as authoritative can inhabit and from which a particular doctrine, law or text can emanate. It is this figure or text that sanctions the image and, at least in the infant's imagination — an imagination that persists as an adult-proscribes what is the desirable mode of being for the subject. At the point that language intersects with this image, however, then the infant knows — at some level — that it cannot hold the gestalt of this image together as a fixed form. The image fragments and the subject struggles to master the image it perceives as the ideal representation of itself. This struggle is performed over and over again for the subject in the gaze of the Other as a performance as plea; an act in search of sanction.

Language — and we might say the language of the law ${ }^{6}$ —is the tool employed to try and hold the fragments together - to engage others in the production of the ideal image of the self. ${ }^{7}$ Language is the effort to employ others in the industry to (re)produce the image. Language, however, is also the moment of entry into the world of others and of other objects, it is the moment of otherness. Language thus indicates that we will never full capture the image or ourselves in our own terms. It is the realization that what we cannot capture everything in our mouths, that there will always be that which alludes us. For Lacan language is castration as the Name-of-the-Father or the Law-of-the-Father; the moment of prohibition when particles are separated from us and we know we will never be all for the mother, or all in the mirror again. Language is thus the product of oedipal law that prohibits the getting of all, as the getting of all the mother's desire, that is, in the idiom of violence, it is the prohibition of the mastery over ourselves as well as

\footnotetext{
${ }^{6}$ For Lacan, 'language begins along with the law' and this is precisely because the instigation of prohibition emerges as the impossibility of capturing all in language (Lacan 2006e: 225).

${ }^{7}$ As Lacan says, "the "ideal-I” ... situates the agency known as the ego, prior to its social determination, in a fictional direction, that will forever remain irreducible for any single individual' (Lacan 2006c: 76).
} 
over the body of another; the cut inserted that makes fragments of our desired identity. The rest of our lives are fraught with trying to get those bits back. We can see this in Freud's grandson's wrangling with the loss of his mother via the cotton reel, as Lacan says: This reel is not the mother reduced to a little ball by some magical game ... it is a small part of the subject that detaches itself from him while still remaining his, still retained' (Lacan 1977: 62). It is those pieces of himself - those the subject has lost but tries to recover in language - that are the pieces in the mirror that he is desperately holding onto. And here is where we can understand the enjoyment of the torturer and certainly some other forms of violent perpetrators (although not all) as an aggressive exercise of this desperation to hold the pieces.

In the action of violence the torturer makes, what we might call, an incision into the flesh of the other before him. This is both real and metaphoric in the sense that flesh is 'the small part of the subject' that the torturer is trying to get back-and sometimes by extracting that flesh from another. Flesh is not only skin however, it is, for Lacan, the conjoining of language with the image, that is, once we have named that piece of ourselves we feel we have lost or are losing, then we understand or symbolise that piece in what has come to be called reality. And we become part of this reality, our flesh has become of the world through the use of symbols to name the piece lost. The taking of this flesh from another is what occurs in the scene of violence, and the object as flesh of another, for the torturer, becomes something which renders a salve to the loss of the parts of the torturer's self. In Lacanian terms the piece that one wants to extract from another is what he calls the objet petit $a$; the object which will fill the lack cut through castration. As Lacan says of intimate relations with others: 'I love you, but, because inexplicably I love in you something more than you - the objet petit a-I mutilate you' (Lacan 1977: 263). But there are dimensions to this intimacy. Why might call them degrees of violence. In the scene of violence where the torturer, as well as some other forms of violent perpetrators, employ the body of the victim to extract this objet, the relation is not with the victim but with the Other who can sanction the significance of the act, or the significance of the object extracted. This relation, as a kind of deference, produces an enjoyment in the sense of an excitement over performing the duties of the Other, an enjoyment of being a good citizen and hence reproducing an image of oneself as desirable-in the gaze of the Other (in the mirror), while at the same time being in proximity to the law which has prohibited precisely this form of getting the piece of 
flesh—as objet petit a-back, getting back what was imagined cut from the body of the subject.

\section{The object of torture}

The object that is cut from the victim might be speech, as in the scene of torture where the words of the tortured are extracted, in Elaine Scarry's terms, to bolster the power of the regime (Scarry 1985). In such a scene the torturer performs, not only as a torturer, but simultaneously bolsters the regimes capacity to author his behaviour as that of a good torturer. Further, in such a scene, the torturer enjoys the production of a reality that he has a priori identified as the reality. The example of torture, particularly in Elaine Scarry's account, offers the specific illustrations of this condition, as a parallel experience of the scene of torture. The regime, in Scarry's terms is what we can think of as the parent, guardian or sovereign, and this figure is embodied in the torturer who is able to decide as to whether the subject lives, dies, or is subjected to mental or physical agony, at the same time as employing language to assert or author a particular realitythe regimes reality. The body of the tortured deteriorates or betrays the victim of torture-through becoming a weapon itself, as in the case of stress positions - at the same time that the torturer re-inscribes or speaks the scene through the language of the regime. The torturer becomes the judge of reality, what a chair, filing cabinet or other ordinary — but no less painful—-tool of the torture signify. ${ }^{8}$ Reality, we might say, is the jurisdiction of the regime in this scene, and, in a very literal sense, the torturer states that the pain can stop, the torture victim can live, ${ }^{9}$ if they obey the codes (as requests) of the torturer. In the film Zero-Dark-Thirty — which is claimed by the filmmakers to be based on 'first hand' accounts of these scenes - the torturer, Daniel Stanton, explains the rules, very succinctly, as he says: 'I own you Ammar. You belong to me. Look at me ... If you don't look at me when I talk to you, I hurt you. If you step off this mat, I hurt you. If you lie to me I’m gonna hurt you. Now look at me' (Bigelow 2012). In this sense the torturer becomes the judge of not only the worth of the body of the subjectwhether it should be hurt, injured or killed—but the judge of whether the tortured are good or bad, qua worthy of life. The torturer —as the screenwriters of Zero-Dark-Thirty

\footnotetext{
${ }^{8}$ I have discussed this dynamic further; see Rogers (2010).

${ }^{9}$ There is a necessary qualifier here, because of course complying to what the torturer requests rarely means the pain will stop. Despite the justifications for torture it is rarely performed in the interests of gaining information. Hence the victim can do very little to appease the torturer, nevertheless, this is the dynamic set up in this scene. Scarry discusses this dynamic at length in Body in Pain (1985).
} 
uncomfortably portray_ own the body of the tortured, that is, they own his reality and (re)produce this reality on their own terms.

In the scene of torture, where the actions of violence perform this as violence in their production of the speech of the tortured, as reflecting the reality of the regime, the torturer affirms his imago in this reality, by (re)producing it through the violence itself. This may resonate with other forms of violence also, as Allen Feldman says, writing on violence in Northern Ireland and in South Africa: 'In the ecozone of violence, such regulatory memory is both constitutive of the self and a mark of personal finitude. Finitude affects not only personhood but collective memory—violence renders everything repeatable in its own mechanical reproduction and everything finite in its defacements' (Feldman 2003: 60). This conjoining of finitude and of repetition has a parallel articulation in Lacanian psychoanalysis as the conjoining of the death drive and the reality principle. Because the production of reality always requires a killing off of other possible interpretations of reality, that is, it is a killing off of other names for the flesh lost. The reel becomes the mother, and at the moment of that mastery-if only for a moment - the child experiences the loss of the mother as bearable, not pleasurable, but not unbearable, almost a relief. ${ }^{10}$ And it is this relief that is repeated in our lives, but to more or less degrees.

For Lacan repetition is an activity of the death drive insofar as it strives to kill off all that might function as an alterity to the reality imagined by the subject. This non-alterity to reality is what Lacan calls the realization of the signifier, that is the production of a finitude to reality. For Lacan: 'the realization of the signifier will never be able to be careful enough in its memorization to succeed in designating the primacy of the significance as such' (Lacan 1977: 61). Repetition occurs because of the impossibility of this designation of primacy — or what we might call the complete designation of reality as reality for all. Repetition is here, what we might think of, as the throwing of the cotton reel out from the child's cot, again and again and again. For most of us, the repetition of the throwing and the feeling of capturing the loss of the mother in language — the 'I miss you' form of language_-is soothing enough. Repetition is an ordinary activity that is, for Lacan, why we continue to speak at all, to repeat the terms we understand, to test them in the world and have them sanctioned by others. But this

\footnotetext{
${ }^{10}$ this is of course why Lacan ties the reality principle to the beyond of the pleasure principle.
} 
need for sanction is what also produces the proximity to prohibition, precisely because we may be wrong. For some repetition is intolerable, conversation, argument, dialogue or difference is intolerable. These things introduce intolerable fragments in the subject's sense of self, as reflective of, or reflected as the nation, the community, the regime. It is then that a desire for finitude insists as a desire for the aggression of the death instinct to the point of infliction into the flesh of another.

\section{The violent desire for finitude}

In one repeated example of the desire for finitude we can see the efforts of the suicide bomber, the jihadist, the martyr. In, at least some, of the violences exercised by 'suicide bombers' is the effort to produce a definitive reality in the flesh of others. This is not necessarily as a desire to die, but as a desire to leave a mark in reality, a mark that endures either in the flesh, polis or political reality of another. The mark of oneself on or in another offers one form of having a desired image of reality reflected in the flesh of another. But this kind of mark also represents both the desperation and the aggressivity of the desire for a mark. The effort to produce reality is painfully represented in the acts and descriptions of Mohamad Siddique Khan, one of the “London bombers" of 2005:

I'm going to keep this short and to the point because it's all been said before by far more eloquent people than me. But our words have no impact upon you therefore I'm going to talk to you in a language that you understand. Our words are dead until we give them life with our blood ... This is how our ethical stances are dictated. Your democratically elected governments continuously perpetuate atrocities against my people and your support of them makes you directly responsible ... Until you stop the bombing, gassing, imprisonment and torture of my people, we will not stop this fight. We are at war and I am a soldier. (Khan cited in Govan, Tweedle \& Stokes 2005: 7)

What Siddique Khan's statement points to is the use of flesh as an attempt to render his reality recognisable in the terms of the Other. His words are 'dead,' but his blood animates them, 'gives them life.' The flesh of himself and that of those he kills forms the objet pettit $a$ - that marks an effort for definitive reality.

For Lacan the objet petit $a$ is a non-specular substance that falls from what he calls the cut in the Other. Its status as non-specular is crucial because it brokers no dissent. That is, it cannot be interpreted by others. Hence the destruction of the flesh of others is crucial for Siddique Khan, and even for this destruction in the form a bombing-where flesh will not be recognizable as anything more than flesh. That is, in his understanding it exists with no specular image. This form of destruction enables him to believe that 
his actions will not be interpreted, that is, for Siddique Khan his actions in the flesh are definitive and signify a definitive reality, they represent the possibility of noninterpretation insofar as they represent the wish for the interpretation that he (imagines) he gives them. ${ }^{11}$

In Siddique Khan's rendition we could say that the flesh of the dead (including himself) as the remainder of the blast, are the words he is trying to make understood with his blood, and the blood of others. To be understood in his terms is of course to have produced his own reality. As Feldman said of the effort to produce reality in the flesh in Northern Ireland 'the historical event is not that which happens but that which is narrated’ (Feldman 2003: 61). Thus Siddique Khan’s action is not only an effort to make himself heard, but to first make himself understandable, to narrate the reality of his experience as one who can speak. ${ }^{12}$ To do this-in a Lacanian sense-he must redefine the codes of the Other, that is reposition the Other as his Other. And, of course, in this representation of the Other we can hear the echo of his prayer 'there is no God but (his) God,' and we might say that for Siddique Khan that there is no reality but (his) reality, that is, there is no Other but the Other, as the Other for him. ${ }^{13}$

The production of this kind of what we might think of as an 'exclusive reality' is a form of psychosis. In the suicide bomber it can be seen as a psychological as well as a political psychosis. It is a moment where nothing exists but the significance offered by the one signifying, that is, to Siddique Khan all others are dead when he dies — there is no living signifier beyond his act. In this way the psychotic can be understood as one who dwells in their own reality - the person in front of them is only a person insofar as they see them as such, if they see them as an object then the psychotic will treat them as such. Because all others are (dead) objects, then the interpretation of reality does not exist precisely because there is no other person to interpret the act differently. Reality simply is what they believe it to be, and then they die (and kill) with that belief.

\footnotetext{
${ }^{11}$ Of course for those injured, for those who lost people in the bombings and for all of us looking on however, there is a great deal of interpretation to be done beyond Siddique Khan's own.

${ }^{12}$ For an excellent discussion of how Siddique Khan's actions can be understood in the register of the ethical, see Pugliese (2010).

${ }^{13}$ I want to ensure here that this point is not misunderstood. A Lacanian discussion of the Other as God is not incongruent with a notion of faith. It is not that Siddique Khan's belief in Allah is only his belief, but that in his inscription of his reality his defers the judgment of his act as the right reality onto Allah who sits for him in the site of judgment. He may be right, but a debate on faith is beyond this discussion.
} 


\section{The psychosis of torture}

For Lacan the psychotic structure is marked by the belief that there is 'no paternity to the signifier,' no law-of-the-father only a law of the self; in this sense it is autonomy in its most extreme form, auto-nomos, self law. In Primo Levi's discussion of the soccer game of the sonderkommando - the work details comprising Jewish prisoners-in Auschwitz we can see the dynamics of this form of perpetration at work, if not the actual individual enjoyments of the most violent of perpetrators (Levi 1989: 55). In the soccer game the brutality of the regime is highlighted through the performance of a regime which enables the utter destruction of people as objects, as 'figuren' in Shoshana Felman's terms (2002), and then the re-animation of them as sporting combatants for the purposes of the game. It is the very structures of the camp which produce these possibilities, for Levi (1989) and for Giorgio Agamben (1999) ${ }^{14}$ — who sees that shift between object and subject and back again —as the most obscene of the performances of the relations between Nazi Germany and the Jews. That the Jews could be treated as supposedly sporting equals and then returned to the position of being able to be killed with impunity, illuminates, for Agamben, the real structure of the camp in which the responsibility for human relation, in our terms, can be allocated into the laws or rules of the camp, and the matter before the sporting participants can be suspended in the interest of other-more playful—rules being applied. But of course all these rules are playful in the most sadistic sense. Because this was, of course, not just a game of soccer but the game of animation of matter, an animation which was only on the terms of the perpetrator.

The soccer game indicates the structure of such an animation, in which the playfulness of the perpetrators is enabled because of the suspension of judgment—and indeed of any sense of relation - and its replacement into the rule, the law, rather than the relation. This suspension indicates a powerfully disturbing and instructive depiction of what the camp can do to people, although offers little by way of thinking responsibility for the participants in the game. For the participants, we could imagine, that the game was enabled by the regime, but this very enabling removed their capacity to see it as more than a game enabled by another. It is when the game is produced in the more-and perhaps truly_intimate scenes of violence, where the perpetrator can both animate and

\footnotetext{
${ }^{14}$ See also Sanyal (2002).
} 
suspend at his or her own whim, that we see the profound enjoyment of some perpetrators as a Lacanian jouissance.

For Lacan jouissance took many forms, but the one that is useful to us here, is that of a bodily jouissance understood as an enjoyment in the flesh, a jouissance that, I will explain, as an encounter with and as law, a moment of proximity to prohibition in which that prohibition becomes unbearable. The frame for jouisance is that of the oedipal scene, previously mentioned. In this scene the limit of the subject is experienced as an encounter with castration evidenced in an imagination of the oedipal scene. For Lacan there is no reality to the oedipal scene, only an experience of it. ${ }^{15}$ The imagination which haunts the child and then the adult becomes for Lacan the defining element to all relations as a desire to thwart the cut of castration. Jouissance can be understood as an effort to thwart castration while at the same time toying with it. If castration is embodied in, what Lacan calls, the law-of-the-father then coming close to that law both produces an excitement — as a terror-and the possibility of knowing where the limits of law begin and end. That is, it produces the tension in knowing the precise coordinates of recognition from the Other. And it is precisely this last production which the sadistic perpetrator enjoys, not only in his flirtation with the limit, but in his embodiment of the father-Fuhrer as the dictator of the limit.

The Other, particularly in the time of war and in scenes of torture, is an Other who can decide who lives and who decides, embodied in the words of the character Daniel in Zero-Dark-Thirty who dictates the limits of pain and of life- 'if you lie to me I hurt you ... I own you' (Bigelow 2012). Daniel, in these scenes is the figure of the father as the dictator of limits and of punishment. But Daniel goes further in the scene of torture where he re-animates the relation between himself and his victims in a mode which makes him not only the figure who can decide on life and death (on pain, or not) but the figure who can produce the form of life the victim experiences. That is, he can animate the tortured within his own parameters.

In the scene of Daniel with the torture victim Ammar ,this dictation of life comes in the form of Daniel torturing in one moment then later coming back to offer Ammar drink,

\footnotetext{
${ }^{15}$ Even the patient known as the Wolf Man in Freud's account does not necessarily see the scene of his parents coitus, but knows the experience and puts image to it. For Lacan this image is what he calls the Imaginary as an imagination of every encounter through the lens of the first trauma of the imagining of the oedipal scene.
} 
food and even a gentle touch in the next moment. This animation of the relation, of course, is the torturer's technique that we have come to know in popular culture (and sometimes in the flesh) as 'good cop, bad cop.' This is usually embodied in two people, but as a technique of torture it is perhaps more effective as an injury to the tortured when embodied in the confusions which haunt the relationship to one person-the torturerOther. ${ }^{16}$ In Zero-Dark-Thirty and perhaps in all scenes of torture, this technique may be both effective and enjoyable to the perpetrator, but the texture of the technique beyond the parameters of its effect in acquiring information is helpful to parse if we are to understand the excitements of the perpetrator in these scenes. ${ }^{17}$ In the scene of torture, such as that illuminated in Zero-Dark-Thirty, Daniel has the sanction of his superiors, and this is crucial to his performance of torture and, in the film, it suggests a more clinical—or perhaps legal—relation is at work; one which relieves Daniel of not only responsibility but of being accused of exercising an enjoyment.

We can see what is going on in the scene of torture as a reanimation of the oedipal scene where the child who imagines the scene imagines himself able to be the author of the scene. This is a getting close to the instance of castration but then far from being subject to it — and its attendant horrors and excitements—it is a recruiting of one's own law to animate the flesh that is denied the child in that moment- the mother's flesh. To understand this we must understand the legal sanction offered to perpetrators of violence in situations of war, that is, how positive law functions to sanction the breach of oedipal law, or how positive law allows - and even demands - the torturer breach the flesh of the another. The breach of flesh is, of course, law's stock-in-trade—as a practice of torture, capital punishment and even detention, but it is also the very thing barred the subject in the oedipal scene. In this scene the figure of the father (this figure could be an actual father or it could be any desirable object or experience the mother has away from the child) prevents the child from consummating his desires for the mother, that is, returning to her flesh; a return to the womb as a form of re-entry into the flesh. ${ }^{18}$

\footnotetext{
${ }^{16}$ The damage of this torture may well be the feelings embodied in trusting another and then the awareness that one's own sense of trust is not to be trusted. This is of course Elaine Scarry's point about the body of the tortured becoming a weapon to itself-more than in the experience of pain, the body as an affectionate/loving entity betrays itself in having any feelings of trust (Scarry 1985).

${ }^{17}$ Perhaps this can also offer substance through which to ponder the torturer's level of responsibility to the community and to the victim.

${ }^{18}$ Note: rape, then, far from being a 'side effect' of war is undoubtedly inherent to it because it performs the subject's own guilt of perpetration - that is, it is an important excess beyond the laws of war, and important component to the guilty subject who knows that the breach of another's flesh is a breach of
} 
This desire for return can be thought of as what is symbolically sanctioned in the commands of war. The soldier is told that his insertion into the flesh of anotherwhether it causes pain death or another form of injury - is a necessary act of war. In war-or in any post war context - the sanction of the destruction of the flesh of another is confusing (or should be confusing), precisely because this is what is barred to the subject prior to war. At the time of war this confusion is likely to be managed by replacing the prohibitive function of the father with the commands of superiors. Thus when a soldier is instructed to kill- to enter the flesh of another with bullet, knife or other mechanism of destruction - the body of the victim becomes not a body at all but an inanimate object, as figuren, or as an object. ${ }^{19}$ This construction enables a belief that oedipal law is enduring no breach, at least for that time. Indeed, contrary to the assumptions of pleasure experienced by people who create the other as object, what I am suggesting here is that the enjoyment is not in the rendering of the other as object, but in the animation of the other at the hands of the perpetrator who imagines themselves able to animate the other as subject to their own law.

\section{Conclusion}

For most soldiers the return to the ordinary law of relations after being subject to the laws/commands of war is traumatic, in varying degrees, precisely because the flesh rendered object begins to return in memory as human flesh; flesh with its own life and flesh subject to the ordinary injunctions of oedipal law. Indeed the return to ordinary life after war should be traumatic if the soldier-subject is to re-orientate themselves to the ordinary law of relations. For some perpetrators in a war however, the confusion of the contradictions between oedipal law and the positive commands of war (what we can call positive law) promote neither post-trauma nor remorse. For some perpetrators the contradictions between oedipal and positive law are precisely what is enjoyable about war and its attendant violences.

In the scene of torture in Zero-Dark-Thirty mentioned above we can see the presumption that the sanction of positive law does not render the other object. For Daniel Stanton they are precisely human others who are able to be breached, that is, the

oedipal law. Rape, as a breach of positive law — despite its sanction by comrades or even superiors—is something for which the subject knows he could be (should be) punished. And punishment is a necessity for the subject who breaches oedipal law.

${ }^{19}$ There is so much writing on the creation of the Other as 'object'; see, for example, Gobodo-Madikizela (2008). 
sanction for the breach is enabled through the sanction of the law. But this breach is a breach of oedipal law. In the scene of torture we see the breach of oedipal law and the attempts to thwart it in the animation of the other's flesh or the other's life. The animation of the matter of the body of another is not only enabled but is psychically made seductive through the sanction of positive law's performance of a breach of oedipal law. Thus what is unacceptable — in oedipal law—but sanctioned —in positive law-precisely enables a enjoyment for the perpetrator in the act of violence. This tension of the command and the unacceptable, in fact, is the perfect formula for a jouissance of the torturer; a formula which demands the subject enjoy the flesh of another in its animation. The enjoyment is precisely in the being in proximity of the law because it also points to the location of where one knows what one is, that is, if the subject knows where the cut will arrive then it also knows what is desirable (in a negative sense) to the mother. The subject's proximity to the cut announces that one is getting warmer in returning to the mother's absolute desire, (or the womb). ${ }^{20}$ Thus the (sovereign or military) law's direction as to what is to be cut, tortured, or killed points to both the oedipal crime and a location in which permeation of the womb can occur. But the subject-on an unconscious level—-knows this is both sanctioned and prohibited at the same time, and, it is this knowledge which produces the animation (playing with) the flesh of another as a form of enjoyment. An enjoyment which must be accounted for in the scene of violence.

\section{Reference List}

Agamben, G. 1999, Remnants of Auschwitz: The Witness and the Archive, (trans.) D. Heller-Roazen. Zone Books, New York.

Balint, J. 2011, Genocide, State Crime and the Law: In the Name of the State. Routledge, London. Bigelow, K. (dir.) 2012, Zero-Dark-Thirty, writer M. Boal. Sony Films, Culver City, CA.

Clemens, J. \& Grigg, R. 2006, ‘A Note on Psychoanalysis and the Crime of Torture,' Australian Feminist Law Journal, vol. 24, no. 2: 161-177, doi: http://dx.doi.org/10.1080/13200968.2006.10854357

'Convention against Torture and Other Cruel, Inhuman or Degrading Treatment or Punishment' 1984, United Nations General Assembly. Online, available: https://treaties.un.org/pages/viewdetails.aspx?src=treaty\&mtdsg no=IV-9\&chapter=4\&lang=en [Accessed 13 June 2010].

de Certeau, M. 1986, Heterologies: Discourse on the Other, (trans.) B. Massumi. University of Minnesota Press, Minneapolis.

Dorfman, A. 1994 [1990], Death and the Maiden. Penguin Books, New York.

Douzinas, C. 2000, The End of Human Rights: Critical Legal Thought at the Turn of the Century. Hart Publishing, Oxford.

\footnotetext{
${ }^{20}$ Children's games often reproduce this form of enjoyment in the efforts to elide discovery on the way to the secure location. The closer one gets to the final goal the more perilous the risk of discovery however-as in the game 'What's the time Mr Wolf?' and its variants.
} 
Feldman, A. 2003, 'Political Terror and the Technologies of Memory: Excuse, Sacrifice, Commodification, and Actuarial Moralities,' Radical History Review, vol. 85: 58-73, doi: http://dx.doi.org/10.1215/01636545-2003-85-58

Felman, S. 2002, The Juridicial Unconscious: Trials and Traumas in the Twentieth Century. Harvard University Press, Cambridge, MA, \& London.

Freud, S. 2001a, From the History of an Infantile Neurosis (The Wolf Man), 1914/1918, SE XVII, (trans.) J. Strachey. Vintage, London. 2001b, Beyond the Pleasure Principle, Group Psychology and Other Works (1920-1922), (trans.) J. Strachey. Vintage, London.

Gobodo-Madikizela, P. 2008, 'Radical Forgiveness: Transforming Traumatic Memory Beyond Hannah Arendt,' in Justice and Reconciliation in Post-Apartheid South Africa, (eds) F. du Bois \& A. du Bois-Pedain. Cambridge University Press, Cambridge: 37-61.

Govan, F., Tweedle, N. \& Stokes, P. 2005, 'In a Measured Yorkshire Accent. The July 7 Suicide Bomber Delivers His Message of Hate,’ The Daily Telegraph, 2 September: 7.

Howe, A. 2008, Sex, Violence and Crime: Foucault and the 'Man' Question. Routledge-Cavendish, Oxon. Lacan, J. 1977, Four Fundamental Concepts of Psychoanalysis: Seminar XI, (ed.) J. A. Miller, (trans.) A. Sheridan. Penguin, London. 1992, Ethics of Psychoanalysis 1959-1960, Book VII, (ed.) J. A. Miller, (trans.) D. Porter. Norton \& Company, New York. 1998, Encore, The Seminar of Jacques Lacan, Book XX: On Feminine Sexuality: The Limits of Love and Knowledge, 1972-1973, (ed.) J. A. Miller, (trans.) B. Fink \& R. Grigg. Norton \& Company, New York. 2006a [1950], 'A Theoretical Introduction to the functions of Psychoanalysis in Criminology,' in Ecrits: The First Complete Edition in English, (trans.) B. Fink \& R. Grigg. Norton \& Company, New York: 103-122. 2006b [1963], 'Kant with Sade,' in Ecrits: The First Complete Edition in English, (trans.) B. Fink \& R. Grigg. Norton \& Company, New York: 645-668. 2006c [1966], 'The Mirror Stage as Formative of the Function of the I as Revealed in Psychoanalytic Experience,' in Ecrits: The First Complete Edition in English, (trans.) B. Fink \& R. Grigg. Norton \& Company, New York: 75-81. 2006d [1948], 'Aggressiveness in Psychoanalysis,' in Ecrits: The First Complete Edition in English, (trans.) B. Fink \& R. Grigg. Norton \& Company, New York: 82-101. 2006e [1953], 'The Function and Field of Speech and Language in Psychoanalysis,' in Ecrits: The First Complete Edition in English, (trans.) B. Fink \& R. Grigg. Norton \& Company, New York: 197-268. 2006f [1954], 'Response to Jean Hyppolite’s Commentary on Freud's Verneinung,' in Ecrits: The First Complete Edition in English, (trans.) B. Fink \& R. Grigg. Norton \& Company, New York: 318-333. 2006g [1960], 'The Subversion of the Subject and the Dialectic of Desire,' in Ecrits: The First Complete Edition in English, (trans.) B. Fink \& R. Grigg. Norton \& Company, New York: 672702.

2007, The Other Side of Psychoanalysis, The Seminar of Jacques Lacan, Book XVII, (trans.), R. Grigg. Norton \& Company, New York.

Langer, L. 1980, 'The Dilemma of Choice in the Death Camps,' Centerpoint, vol. 4: 222-231.

Levi, P. 1988, The Drowned and the Saved, (trans.) R. Rosenthal. Summit Books, New York.

'Memorandum for John Rizzo, Acting General Counsel of the Central Intelligence Agency' 2002, United States Department of Justice, Office of Legal Counsel, 1 August. Online, available: http://dspace.wrlc.org/doc/bitstream/2041/70967/00355_020801_004display.pdf [Accessed 13 June 2010].

Military Commissions Act, 10 USC. 2006, HR-6166, 109 ${ }^{\text {th }}$ Congress of the USA, 2005-2006. Online, available: https://www.govtrack.us/congress/bills/109/hr6166/text [Accessed 13 June 2010].

Mill, J. S. 1974 [1859], On Liberty. Penguin, Harmondsworth.

Polanski, R. (dir.) 1994, Death and the Maiden. Capitol Films, Los Angeles.

Pugliese, J. 2010, ‘Necroethics of Terrorism,’ Law \&Critique, vol. 32: 213-231, doi: http://dx.doi.org/10.1007/s10978-010-9074-X

Rogers, J. 2010, ‘Torture: A Modicum of Recognition,' Law \& Critique, vol. 32: 233-245, doi: http://dx.doi.org/10.1007/s10978-010-9075-9 2013, Law's Cut On the Body of Human Rights: Female Circumcision, Torture and Sacred Flesh. Routledge, London. 
Sands, P. 2008, Torture Team: Rumsfeld's Memo and the Betrayal of American Values. Palgrave McMillan, New York.

Sanyal, D. 2002, 'A Soccer Match in Auschwitz: Passing Culpability in Holocaust Criticism,' Representations, vol. 79: 1-27, doi: http://dx.doi.org/10.1525/rep.2002.79.1.1

Scarry, E. 1985, Body in Pain: The Making and Unmaking of the World. Oxford, New York.

Winterson, J. 1992, Written on the Body. Jonathan Cape, London.

Zizek, S. 2013, 'Zero Dark Thirty: Hollywood's Gift to American Power,' 26 January. Online, available: http://www.theguardian.com/commentisfree/2013/jan/25/zero-dark-thirty-normalises-tortureunjustifiable [Accessed: 27 January 2013]. 